\title{
The Pyrolysis of Tobacco Additives As A Means of Predicting Their Behaviour in A Burning Cigarette*
}

\author{
by \\ Steve Stotesbury, Helena Digard, Louise Willoughby and Andy Couch \\ British American Tobacco, \\ Regents Park Road, \\ Millbrook, Southampton, SO15 8TL, United Kingdom
}

\section{SUMMARY}

In order to understand the behaviour of tobacco additives in the burning cigarette it is important to know whether they transfer intact to the smoke or whether there is any decomposition during smoking. There are practical problems in comparing the chemical analysis of whole smoke from cigarettes with and without additives. Changes to the smoke chemistry may be insignificant in analytical terms and therefore missed from a general scan. Targeted analysis of key components potentially overcomes this concern, but has the drawback of being expensive in terms of time and analytical resources. Pyrolysis-GC-MS is an attractive solution in that it potentially enables the effects of combustion of a single material to be studied in isolation. However, it is not entirely valid to base an assessment of a material on a pyrolysis experiment alone unless the results can be demonstrably related to the cigarette smoke chemistry. The variables that affect the outcome of combustion are temperature, rate of change of temperature, oxygen concentration and chemical environment (matrix and gas phase). The key to this work has been in performing pyrolysis experiments under a range of different conditions and relating the experimental conditions to those within the burning zone of the cigarette to give a prediction of smoke chemistry. To test the theory in practise, the transfer and the extent of degradation of anisole, $p$-anisaldehyde, benzaldehyde, isoamyl isovalerate, methyl trans-cinnamate and vanillin within a burning cigarette were investigated using this pyrolysis method. Pyrolyses were undertaken on each additive at 14 sets of pyrolysis conditions: temperatures between $200^{\circ} \mathrm{C}$ and $700{ }^{\circ} \mathrm{C}$ in $2 \%$ and $10 \%$ oxygen, and at $800^{\circ} \mathrm{C}$ and $900^{\circ} \mathrm{C}$ in $2 \%$ oxygen. By monitoring the presence of the intact additive in the volatile components from the pyrolysis, the temperature at which the additive is likely to transfer to the smoke was determined. By monitoring the decomposition products at temperatures up to this transfer temperature, the extent and products of decomposition likely from the additive were estimated.

The pyrolysis predictions were compared with results from a previous study involving adding ${ }^{14} \mathrm{C}$-analogues of the materials to cigarettes and measuring the resultant radioactive species in the smoke. The results from the pyrolysis experiments lead us to make the following predictions:

$\diamond$ Anisole, isoamyl isovalerate and vanillin will transfer intact to the smoke at $200^{\circ} \mathrm{C}$.

$\diamond \quad p$-Anisaldehyde and methyl trans-cinnamate are likely to transfer to the smoke at a higher temperature of around $400{ }^{\circ} \mathrm{C}$ leading to some decomposition/oxidation ( $3 \%$ and $1 \%$, respectively).

$\diamond \quad$ Benzaldehyde is likely to transfer to the smoke at $200{ }^{\circ} \mathrm{C}$, but at this temperature a significant amount ( $26 \%)$ oxidises to benzoic acid. Both compounds appear resilient to further degradation at higher temperatures.

These levels of transfer were found to be consistent with smoke chemistry data. [Beitr. Tabakforsch. Int. 18 (1999) 147-163]

*Received: 15th December 1998 - accepted: 23rd February 1999 


\section{ZUSAMMENFASSUNG}

Um das Verhalten von Tabakadditiven in einer brennenden Cigarette zu verstehen, ist es wichtig zu wissen, ob die Additive unverändert in den Hauptstromrauch übergehen oder ob während des Rauchens Zersetzungsprozesse stattfinden. Technische Probleme ergeben sich beim Vergleich einer chemischen Analyse des Gesamtrauchs von Cigaretten mit und ohne Additivzusatz. Veränderungen in der Rauchzusammensetzung können analytisch nicht erfassbar sein und blieben deshalb unerkannt. Dieses Problem kann zwar möglicherweise durch eine gezielte Analyse von Schlüsselkomponenten geklärt werden, die Methode hat jedoch den Nachteil, dass sie zeitintensiv und analytisch aufwendig ist. Eine Pyrolyse-GC-MS ist bei dieser Fragestellung ein attraktiver Ansatz, da hierdurch möglicherweise die Auswirkungen der Verbrennung einzelner Substanzen isoliert untersucht werden können. Es ist jedoch nicht vollkommen gerechtfertigt, die Bewertung einzelner Substanzen nur auf ein Pyrolyseexperiment zu stützen, es sei denn, es läßt sich nachweislich ein Zusammenhang zwischen den Pyrolyseergebnissen und der Cigarettenrauchchemie belegen. Die Variablen, die sich auf eine Verbrennung auswirken, sind Temperatur, Geschwindigkeit der Temperaturveränderungen, Sauerstoffkonzentration und chemisches Milieu (Matrix und Gasphase). Der Hauptansatz dieser Arbeit bestand darin, Pyrolyseexperimente unter einer Reihe verschiedener Versuchsbedingungen durchzuführen und dabei auf die experimentellen Bedingungen in der Glutzone der brennenden Cigarette Bezug zu nehmen, um Vorhersagen über die Rauchchemie machen zu können. Um diese Theorie in der Praxis zu testen, wurde in einer brennenden Cigarette mit Hilfe dieser pyrolytischen Methode der Übergang in den Hauptstromrauch und das Ausmaß der Zersetzung von Anisol, p-Anisaldehyd, Benzaldehyd, Isoamylvalerianat, Methyl-trans-zinnamat und Vanillin untersucht. Die Verbrennungen wurden für jedes Additiv unter 14 festgesetzten Pyrolysebedingungen durchgeführt: Bei Temperaturen zwischen $200^{\circ} \mathrm{C}$ und $700^{\circ} \mathrm{C}$ in $2 \%$ und $10 \%$ Sauerstoff sowie bei $800^{\circ} \mathrm{C}$ und $900{ }^{\circ} \mathrm{C}$ in $2 \%$ Sauerstoff. Durch den Nachweis des Vorkommens unzersetzter Additive bei den flüchtigen Produkten wurde die Temperatur festgelegt, bei der ein Übergang des Additivs in den Rauch wahrscheinlich ist. Durch die Erfassung der Zersetzungsprodukte bei Temperaturen bis zur entsprechenden Transfertemperatur wurden das Ausmaß der Zersetzung und die Zersetzungsprodukte bestimmt, von denen man annehmen kann, dass sie aus den Additiven herrühren. Die Pyrolysevorhersagen wurden mit den Ergebnissen einer früheren Studie verglichen, bei der Cigaretten ${ }^{14} \mathrm{C}$-markierte analoge Substanzen zugesetzt wurden und die entste- henden radioaktiven Verbindungen im Rauch gemessen wurden. Aus den Ergebnissen der Pyrolyseexperimente leiten wir folgende Vorhersagen ab:

$\diamond \quad$ Anisol, Isoamylvalerianat und Vanillin werden bei $200^{\circ} \mathrm{C}$ unverändert in den Rauch übergehen;

$\diamond \quad p$-Anisaldehyd und Methyl-trans-zinnamat gehen wahrscheinlich bei höheren Temperaturen von ungefähr $400^{\circ} \mathrm{C}$ in den Rauch über und führen zu leichter Zersetzung/Oxidation (3 \% bzw. $1 \%$ );

$\diamond$ Benzaldehyd wird wahrscheinlich bei $200{ }^{\circ} \mathrm{C}$ in den Rauch transferiert, bei dieser Temperatur oxidiert jedoch ein großer Teil ( 26\%) zu Benzoesäure. Beide Substanzen scheinen bei höheren Temperaturen weiterem Zerfall zu widerstehen.

Die Transferraten befinden sich in Übereinstimmung mit den Ergebnissen der Rauchuntersuchungen. [Beitr. Tabakforsch. Int. 18 (1999) 147-163]

\section{RESUME}

Pour comprendre le comportement des additifs de tabacs dans une cigarette brûlante il est important de savoir si ces additifs restent intacts lors du transfert dans la fumée ou si les additifs sont modifiés par la pyrolyse. La comparaison de l'analyse chimique de la fumée entière de cigarettes avec et sans additifs mène à des problèmes de praticabilité. Les changements dans la composition de la fumée peuvent être non décelable analytiquement et seront ainsi imperceptible. L'analyse appropriée de composants clé potentiellement résout ce problème mais engendre des coûts en temps et en ressources. La méthode GC-MS pyrolytique est une approche intéressante en ce qu'elle permet d'étudier séparément les effets de combustion d'un composant individuel. Cependant, il n'est pas entièrement valide de baser l'évaluation d'une matière sur un seul essai de pyrolyse, à moins que les résultats obtenus ne soient liés d'une façon vérifiable à la chimie de la fumée de cigarette. Les variables qui influencent les résultats d'une combustion sont la température, la concentration d'oxygène et le milieu chimique (matrice et phase gazeuse). L'approche de cette étude consistait à exécuter des essais de pyrolyse sous des conditions différentes et à adapter les régimes expérimentaux aux conditions présentes dans le cône de combustion pour prédire la chimie de la fumée. Pour éprouver la théorie en pratique le transfert et le degré de dégradation de l'anisole, du $p$-anisaldéhyde, du benzaldéhyde, de l'isoamyl isovalérate, du méthyl trans-cinnamate et de la vanilline dans une cigarette brûlante ont été examinés par cette méthode de pyrolyse. Les pyrolyses ont été réalisées pour chacun des additifs sous 14 différentes conditions: entre $200{ }^{\circ} \mathrm{C}$ et $700{ }^{\circ} \mathrm{C}$ dans de l'oxygène à $2 \%$ et à 
$10 \%$, à une température de $800^{\circ} \mathrm{C}$ et de $900^{\circ} \mathrm{C}$ dans de l'oxygène à $2 \%$. En examinant la présence de l'additif intact parmi les composants volatils de pyrolyse, la température à laquelle l'additif est probablement transféré dans la fumée a été déterminé. En examinant les produits de décomposition jusqu'aux températures atteignant cette température de transfert, la dimension de la décomposition et les produits potentiels de pyrolyse de l'additif ont été estimés. Les prédictions de pyrolyse ont été comparées avec les résultats d'une étude précédente dans laquelle ${ }^{14} \mathrm{C}$-analogues de ces additifs avaient été ajoutés aux cigarettes et dont les matériaux radioactifs dans la fumée avaient été mesurés. Les résultats de cet essai de pyrolyse nous amènent à faire les prédictions suivantes:

$\diamond \quad$ L'anisole, l'isoamyl isovalérate et la vanilline vont passer non dégradés dans la fumée à $200^{\circ} \mathrm{C}$.

$\diamond \quad$ Le $p$-anisaldehyde et le methyl trans-cinnamate vont passer dans la fumée aux températures d'environ $400{ }^{\circ} \mathrm{C}$ et seront légèrement dégradés/oxydés ( $3 \%$ et $1 \%$ respectivement);

$\diamond \quad$ Le benzaldéhyde va probablement passer dans la fumée à $200^{\circ} \mathrm{C}$, mais à cette température une parti significative $(\sim 26 \%)$ va oxyder en acide benzoïque. Tous les deux composés s'avèrent résilients à d'autres dégradations aux températures plus élevées.

Les taux de passage déterminés correspondent aux données de la chimie de la fumée. [Beitr. Tabakforsch. Int. 18 (1999) 147-163]

\section{INTRODUCTION}

Cigarette smoke is a complex mixture containing over 4000 known chemical components. In the analysis of smoke, there is often a need to overcome chromatographic and spectroscopic interferences, to prevent ageing of the sample and the need to extract analytes from both vapour and particulate phases. Scan techniques of smoke have been developed to the point where good semi-quantitative data can be obtained for many compounds, but the effect of a single cigarette design change such as introducing a new additive may not be readily discerned when comparing scans of the total smoke.

If smoke scan techniques prove to be too crude for a particular application, then the analytical regime must include specific methods which are targeted to only a limited number of related smoke components at a time. This multiplies the cost and time of the whole process by as many different analyses as are deemed necessary. Substances such as flavours are sometimes added to cigarettes. In order to understand the behaviour of tobacco additives in the burning cigarette it is important to know whether they transfer intact to the smoke or whether there is any decomposition during transfer. Thus, there is a role for an analytical technique providing rapid testing of potential new products or additives, that is able to determine their effect upon smoke composition. Pyrolysis GC-MS has been extensively used within the industry in the past to assess the potential effect of individual cigarette components on smoke composition (1-3). Furthermore, a pyrolysis scan can cover a large range of different components in a single run and the information obtained will be specific to the substance under evaluation, i.e., not hidden by other smoke constituents. However, it is important that the experimental pyrolysis conditions relate as closely as possible to actual conditions within the burning cigarette. A recent review on smoke chemistry uncovered the following quotation:

"In laboratories we often do simplified experiments under arbitrary and artificial conditions because it is easier to do things that way. We forget that these conditions may be quite unlike those experienced by human smokers ..."(2)

Different groups of workers have used different approaches - many have performed pyrolysis experiments in an inert atmosphere, some at an average coal temperature $\left(600^{\circ} \mathrm{C}\right.$ to $\left.700^{\circ} \mathrm{C}\right)$, others at a peak temperature of $850^{\circ} \mathrm{C}$.

In one example of the pyrolysis of menthol (3), the experiments were conducted at $600{ }^{\circ} \mathrm{C}$ and $860^{\circ} \mathrm{C}$. The amount of menthol transfer was found to be $78 \%$ at $600{ }^{\circ} \mathrm{C}$, but only $16 \%$ at $860^{\circ} \mathrm{C}$. For comparison, the level of menthol transferring to the smoke in a burning cigarette containing menthol has been estimated through radio-labelling to be close to $99 \%$ (4). Also, at $860^{\circ} \mathrm{C}, 400 \mu \mathrm{g}$ of benzo[a]pyrene and $2 \mathrm{mg}$ of phenol per gram of menthol were measured in the pyrolysis products. The conclusion from the pyrolysis results was that menthol is likely to add significantly to the chemical and biological effects of the smoke when added to cigarettes (3). Results such as this have led to the usefulness of pyrolysis methods in the assessment of smoke chemistry being viewed with some scepticism.

In pyrolysis experiments the balance of evolved products is highly dependent on the pyrolysis conditions. Temperature and pyrolysis atmosphere are the key controllable variables in such experiments. Correspondingly therefore, the balance of smoke components produced from a cigarette must depend upon the range of conditions that exist within the burning zone of the cigarette. These key conditions include combustion temperature and combustion atmosphere, which in the cigarette vary from ambient to $900{ }^{\circ} \mathrm{C}$, and between 0 and $14 \%$ oxygen in nitrogen. Harder to model, but important to consider are the rate of change of temperature, especially during the puff, and chemical interactions, which are possible among many of the substances from the tobacco matrix and the gas phase within the burning zone. The volatility of the additive is also fun- 


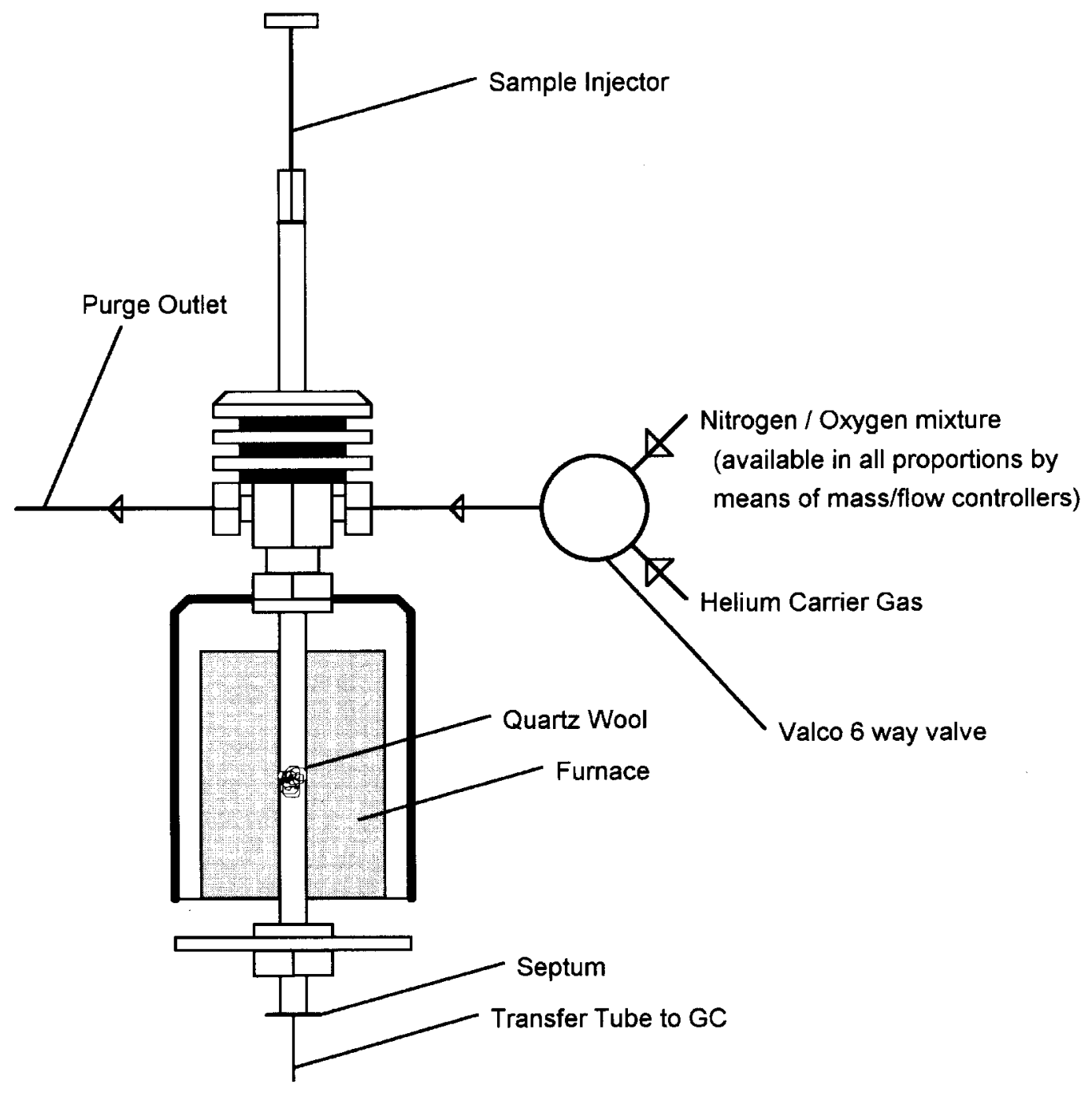

Figure 1.

Diagram of pyrojector II.

damental - a volatile additive is much more likely to transfer to the smoke by distillation at a relatively lower temperature with little degradation.

In this paper, an attempt to consider as many of the conditions in the burning zone of the cigarette as possible is presented. Reproducing the temperature and combustion atmosphere is straightforward, whereas consideration of the dynamic conditions: rate of change of temperature, and potential chemical interactions, are not at all easy to reproduce under laboratory conditions. The rate of change of temperature will be discussed further in the section entitled 'Modelling Cigarette Combustion Chemistry with Pyrolysis Data'. Of course, the only effective measure is to assess how well the results from pyrolysis agree with actual smoke chemistry.

In this paper the pyrolysis method is used to assess the probable behaviour of anisole, $p$-anisaldehyde, benzaldehyde, isoamyl isovalerate, methyl trans-cinnamate and vanillin within a burning cigarette and to predict the percentage transfer. These predictions will be related to smoke chemistry data from cigarettes incorporating radiolabelled $\left({ }^{14} \mathrm{C}\right)$ analogues of these additives reported by GREEN, CHALMERS and KINNARD (5). The possibility of decomposition products occurring in the mainstream smoke was thoroughly examined by GREEN and his colleagues and these data provide a useful basis to validate the pyrolysis results.

\section{EXPERIMENTAL DETAILS}

\section{Pyrolysis method}

A SGE Pyrojector II was modified to allow heating of samples in different atmospheres. Temperature was controllable from ambient up to $900^{\circ} \mathrm{C}$, and by means of a Valco valve, the pyrolysis chamber was flushed with a simulated combustion atmosphere, a controlled concentration of oxygen in nitrogen, prior to the sample insertion (see Figure 1). The simulated combustion 
Table 1.

Instrumental operating conditions.

\begin{tabular}{|c|c|c|}
\hline Gas chromatograph & Analysis of smoke extract & $\begin{array}{c}\text { Analysis of volatile products from } \\
\text { pyrolysis }\end{array}$ \\
\hline Instrument & HP 6890 & HP 6890 \\
\hline GC Inlet & & EPC CIS4 Inlet \\
\hline Injection mode & Split & Split \\
\hline Split flow & $20 \mathrm{~mL} / \mathrm{min}$ & $10.7 \mathrm{~mL} / \mathrm{min}$ \\
\hline Split ratio & & $20: 1$ \\
\hline Column & HP 5 & HP 5 \\
\hline \multicolumn{3}{|l|}{ Column dimensions } \\
\hline Length & $30 \mathrm{~m}$ & $30 \mathrm{~m}$ \\
\hline Inside diameter & $250 \mu \mathrm{m}$ & $250 \mu \mathrm{m}$ \\
\hline Film thickness & $0.25 \mu \mathrm{m}$ & $0.25 \mu \mathrm{m}$ \\
\hline Injector temperature & $250^{\circ} \mathrm{C}$ & $\begin{array}{l}150^{\circ} \mathrm{C} \text { held for } 3 \text { mins: Ramp to } \\
300^{\circ} \mathrm{C} \text { at } 10^{\circ} \mathrm{C} / \mathrm{min}\end{array}$ \\
\hline Eluant gas & Helium & Helium \\
\hline Flow rate & $1.0 \mathrm{~mL} / \mathrm{min}$ & $1.0 \mathrm{~mL} / \mathrm{min}$ \\
\hline Column mode & Constant flow & Constant flow \\
\hline Initial temperature & $40^{\circ} \mathrm{C}$ & $40^{\circ} \mathrm{C}$ \\
\hline Initial time & $3.00 \mathrm{~min}$ & $3.00 \mathrm{~min}$ \\
\hline Ramp rate 1 & $10^{\circ} \mathrm{C} / \mathrm{min}$ & $10^{\circ} \mathrm{C} / \mathrm{min}$ \\
\hline Final temperature & $210^{\circ} \mathrm{C}$ & $210^{\circ} \mathrm{C}$ \\
\hline Total run time & $35 \min$ & $35 \mathrm{~min}$ \\
\hline \multicolumn{3}{|l|}{ Mass spectrometer } \\
\hline Instrument & HP 5972 MSD & HP 5973 MSD \\
\hline Mass range & $33-400 \mathrm{amu}$ & $40-550 \mathrm{amu}$ \\
\hline Scan rate & 2.07 scans $/ \mathrm{sec}$ & $2.89 \mathrm{scans} / \mathrm{sec}$ \\
\hline Solvent delay & $3.00 \mathrm{~min}$ & $3.00 \mathrm{~min}$ \\
\hline Accelerating voltage & $1500 \mathrm{~V}$ & $1250 \mathrm{~V}$ \\
\hline MS Quad & Not measured & $106^{\circ} \mathrm{C}$ \\
\hline MS Source & $280^{\circ} \mathrm{C}$ & $230^{\circ} \mathrm{C}$ \\
\hline
\end{tabular}

Pyrolyser/furnace

(see figure 1 for a diagram of the pyrolysis unit.)

Temperature

Combustion gas composition

Carrier gas
$\mathrm{N} / \mathrm{A}$

N/A

N/A
$200,300,400,500,600,700$ 800 or $900{ }^{\circ} \mathrm{C}$

Oxygen/nitrogen at either $2 \% / 98 \%$ or $10 \% / 90 \%$

Helium 
atmosphere was prepared on-line from separate sources of oxygen and nitrogen by means of mass flow controllers. For each of the six flavours (anisole, $p$-anisaldehyde, benzaldehyde, isoamyl isovalerate, methyl trans-cinnamate and vanillin) fourteen experiments were carried out, under different sets of conditions. The test conditions were varied with respect to both oxygen concentration and temperature to reflect a range of known conditions in the coal of a cigarette (6). These levels were: $2 \%$ and $10 \%$ oxygen at temperatures of $200^{\circ} \mathrm{C}, 300^{\circ} \mathrm{C}, 400{ }^{\circ} \mathrm{C}, 500^{\circ} \mathrm{C}, 600^{\circ} \mathrm{C}, 700^{\circ} \mathrm{C}$ and just $2 \%$ oxygen at $800^{\circ} \mathrm{C}$ and $900^{\circ} \mathrm{C}$.

A small sample (approximately $1 \mathrm{mg}$ ) of each flavour was collected in a capillary tube and weighed prior to insertion into the preheated pyrolyser/furnace which was then flushed with the simulated combustion atmosphere. Thirty seconds after the sample had been inserted into the furnace, the resulting vapours were injected onto the gas chromatograph. GC-MS conditions are listed in full in Table 1.

Peak assignments in the GC-MS chromatograms were made using an on-line library, the Wiley Registry of Mass Spectral Data, 6th Edition, by F.W. McLafferty. Peak areas were obtained from the chromatogram by integration, and the relative significance of the data from each of the sets of conditions with respect to cigarette smoke formation was estimated using weighting factors derived from the frequency of different sets of temperature and oxygen conditions within the burning zone. The derivation of the weighting factors will be explained in the next section.

By monitoring the presence of the intact additive in the volatile components from the pyrolysis experiments, the temperature at which the additive is likely to transfer to the smoke can be determined. By monitoring the presence of decomposition products at temperatures up to this transfer temperature, the extent and products of additive decomposition can be estimated as it transfers to the smoke.

\section{Analysis of mainstream smoke from cigarettes spiked with} benzaldehyde

A solution of $10 \mathrm{mg} \mathrm{ml}^{-1}$ benzaldehyde in ethanol was prepared. From a batch of 80 flue-cured cigarettes, 20 were spiked by injecting each with $10 \mu \mathrm{L}$ (i.e. $100 \mu \mathrm{g}$ benzaldehyde) and 20 by injecting each with $50 \mu \mathrm{L}$ (i.e. $500 \mu \mathrm{g}$ benzaldehyde) of this solution. A further 20 cigarettes were spiked by injecting each with $50 \mu \mathrm{L}$ of ethanol and the remaining 20 cigarettes were used as a control. The cigarettes were then conditioned for 48 hours to allow equilibration to occur.

Each set of 20 cigarettes was smoked using a Borgwaldt smoking engine and the mainstream smoke from each batch was collected by electrostatic precipitation onto glass tubes. After each smoking, the material in the glass tube was washed with $5 \mathrm{~mL}$ methanol into a stoppered flask. A $2 \mu \mathrm{L}$ aliquot of each solution was injected onto a Hewlett Packard 6890/5972 GC-MS using the conditions listed in Table 1.

\section{Modelling cigarette combustion chemistry with pyrolysis data}

The burning zone is illustrated simply in Figure 2. In the model, the burning zone is represented by a series of adjacent cubes, each with dimensions $0.2 \times 0.2 \times$ $0.2 \mathrm{~mm}$. There are four primary variables which will affect the results of combustion of components within each cube, these are temperature, atmosphere, rate of change of temperature and the chemical environment (including interactions with the matrix and gas phase components).

R.R. BAKER has produced a series of plots of gas temperature and oxygen concentration within the burning zone of the cigarette at points in time between 0 and 6 seconds from the start of the puff (6), see Figure 3.

If a grid, $0.2 \mathrm{~mm} \times 0.2 \mathrm{~mm}$, is superimposed onto each

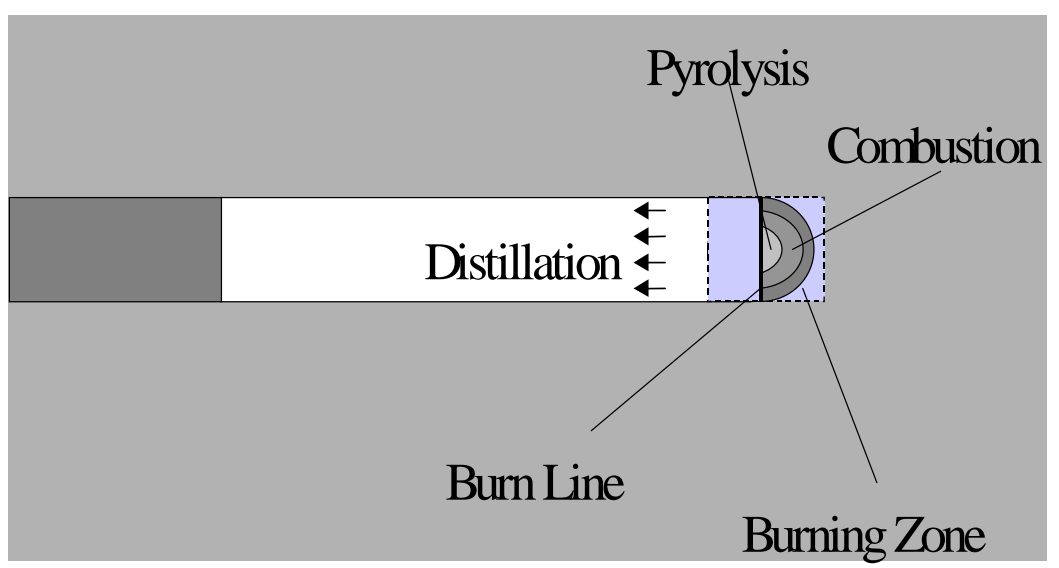

Figure 2.

The burning cigarette. 


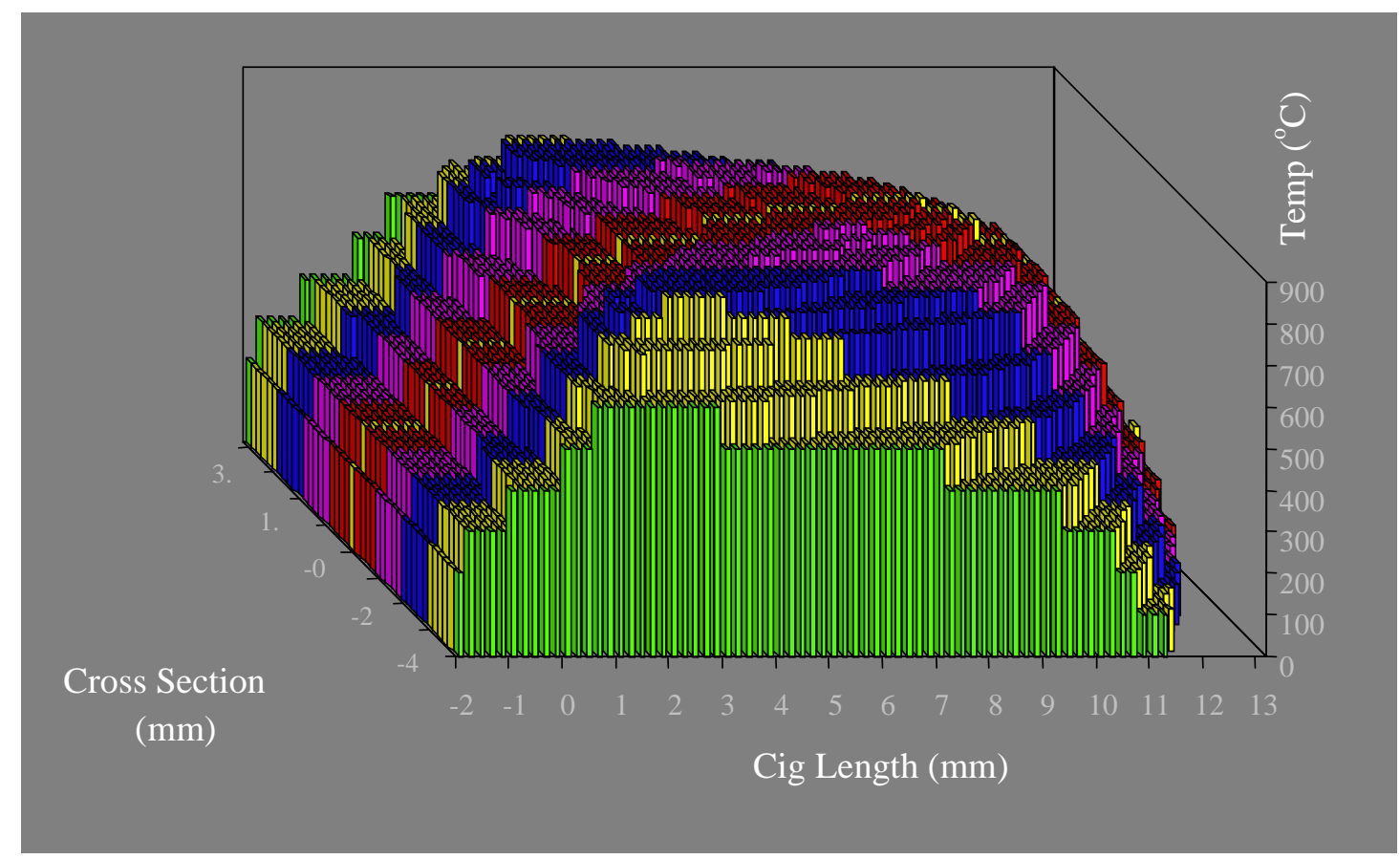

a. Temperature

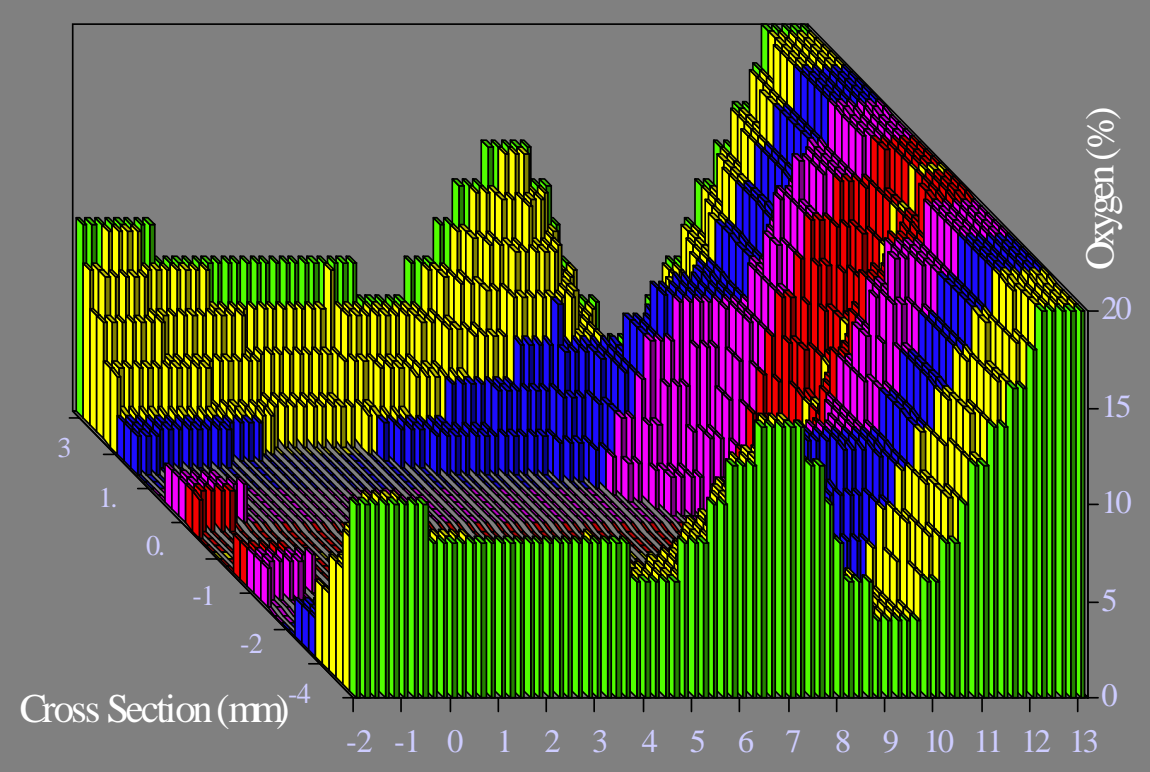

Gig Length $(\mathrm{mm})$

Figure 3.

Burning zone conditions; a. Temperature, b. Oxygen concentration.

each of the plots, an estimate of the conditions to with in $\pm 50{ }^{\circ} \mathrm{C}$ and $\pm 1 \%$ oxygen can be made for each 'cube' at a point in time.

Figure 4 shows a plot of the changing combustion con- ditions at three points during the first three seconds of the puff:

(i) a point at the centre of the cigarette, on the burning line at the start of the puff; 
Temperature $\left({ }^{\circ} \mathrm{C}\right)$

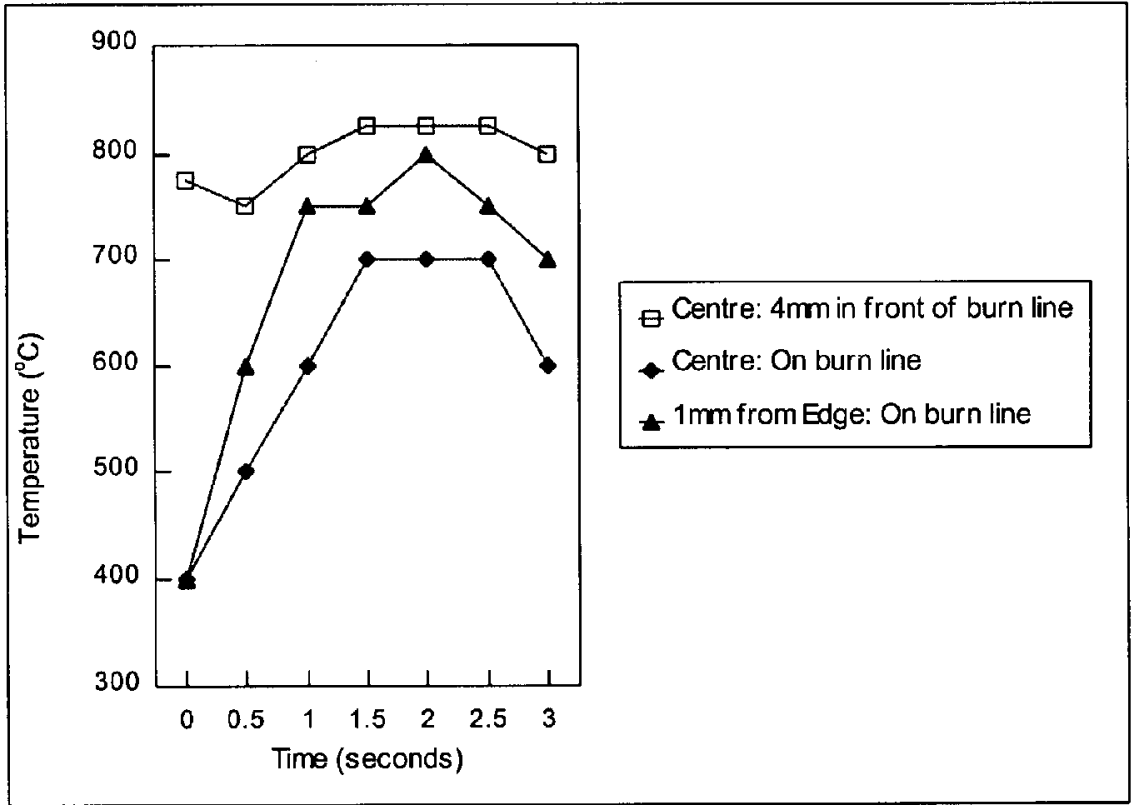

Oxygen Concentration (\%)

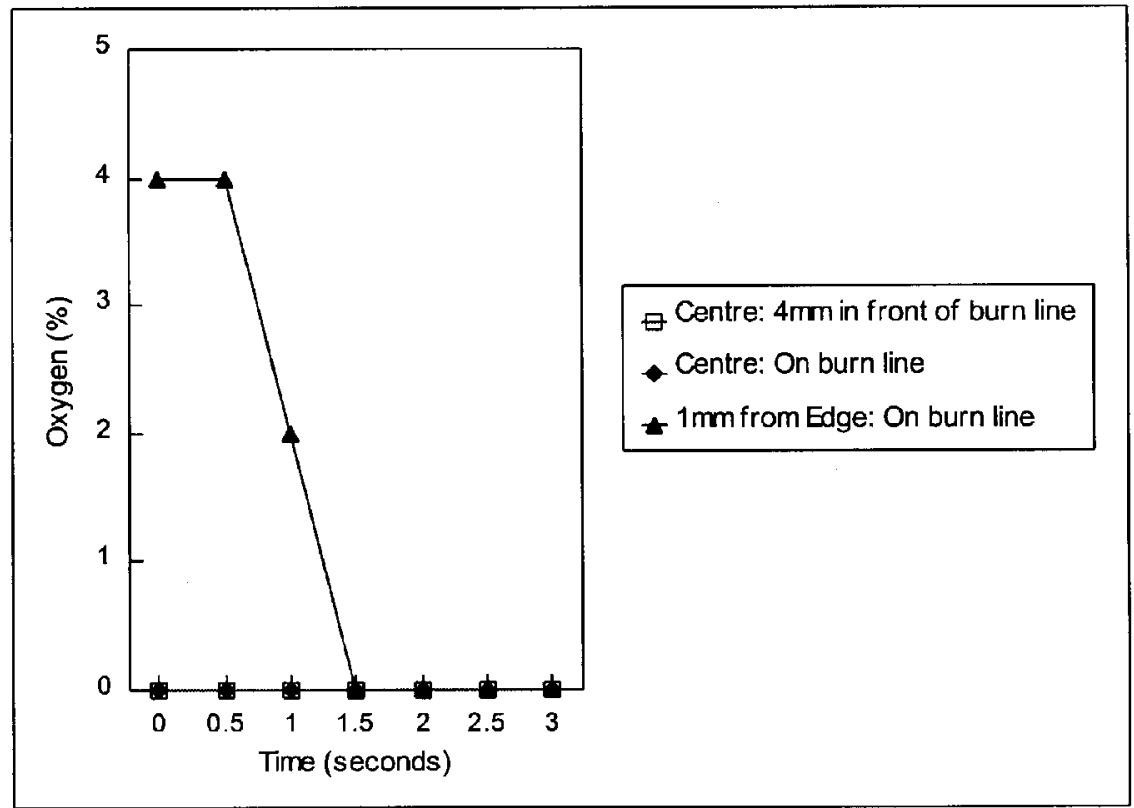

Figure 4.

Combustion conditions during puff.

(ii) a point $1 \mathrm{~mm}$ inside the edge of the paper, on the burning line at the start of the puff;

(iii) a point at the centre of the cigarette, $4 \mathrm{~mm}$ in front of the burning line.
Both temperature and oxygen concentration conditions plateau for a few seconds at each of the points under consideration. This enables the rate of change variable to be effectively ignored - which is fortunate because 


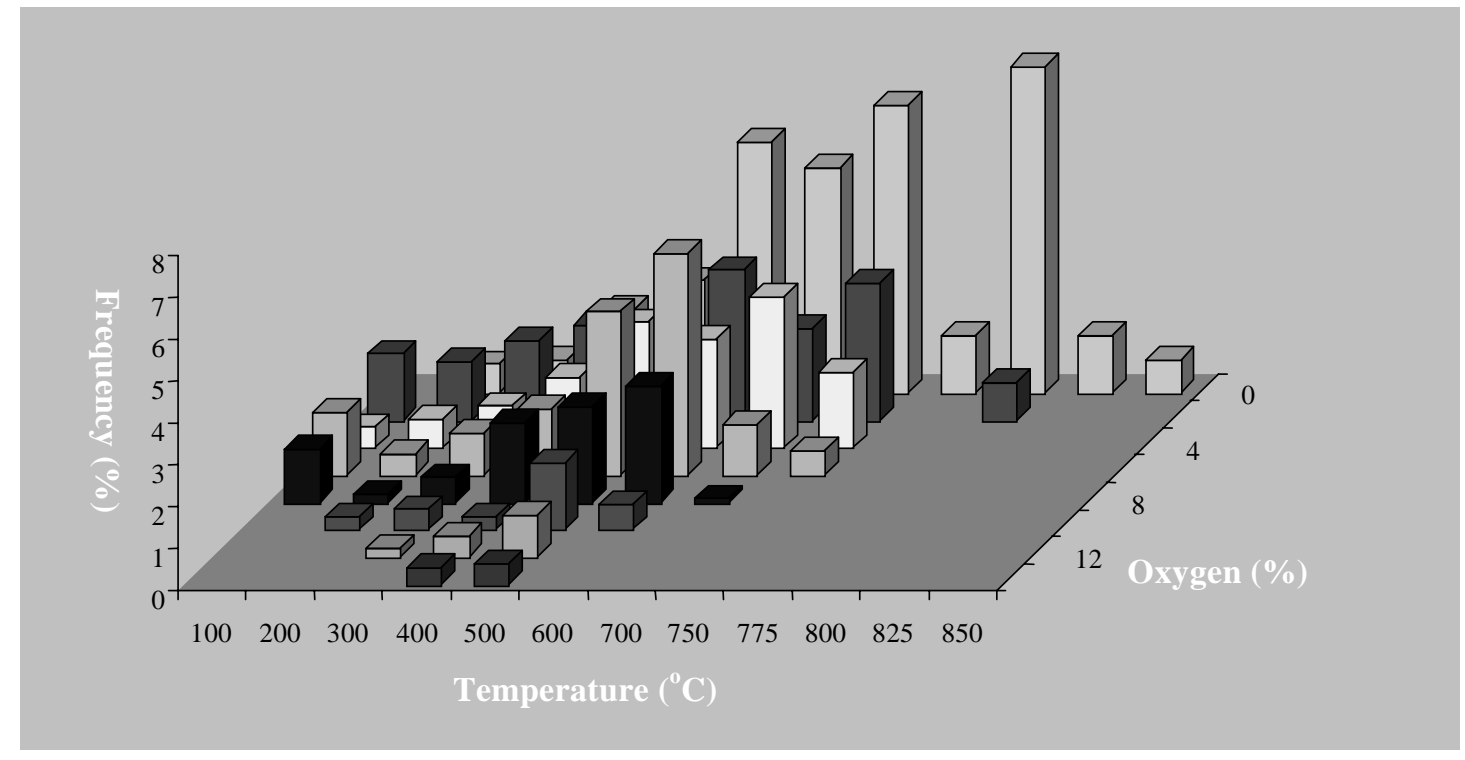

Coal Conditions - Weighting Factors

\begin{tabular}{|c|c|c|c|c|c|c|c|c|c|c|c|c|c|}
\hline & \multicolumn{13}{|c|}{ Temperature $\left({ }^{\circ} \mathrm{C}\right)$} \\
\hline $\begin{array}{c}\text { Oxygen } \\
\text { Content } \\
(\%)\end{array}$ & 100 & 200 & 300 & 400 & 500 & 600 & 700 & 750 & 775 & 800 & 825 & 850 & Total \\
\hline 0 & & 0.7 & 0.8 & 2.0 & 2.7 & 6.0 & 5.4 & 6.9 & 1.4 & 7.8 & 1.4 & 0.8 & 35.8 \\
\hline 2 & 1.6 & 1.4 & 1.9 & 2.3 & 1.1 & 3.6 & 2.2 & 3.3 & & 0.9 & & & 18.2 \\
\hline 4 & 0.5 & 0.7 & 1.0 & 1.7 & 3.0 & 2.6 & 3.6 & 1.8 & & & & & 15.0 \\
\hline 6 & 1.5 & 0.5 & 1.0 & 1.6 & 3.9 & 5.3 & 1.2 & 0.6 & & & & & 15.6 \\
\hline 8 & 1.3 & 0.2 & 0.6 & 1.9 & 2.3 & 2.8 & 0.1 & & & & & & 9.3 \\
\hline 10 & & 0.3 & 0.5 & 0.3 & 1.6 & 0.6 & & & & & & & 3.4 \\
\hline 12 & & & 0.2 & 0.5 & 1.0 & & & & & & & & 1.7 \\
\hline 14 & & & & 0.4 & 0.5 & & & & & & & & 0.9 \\
\hline 16 & & & & & & & & & & & & & \\
\hline 18 & & & & & & & & & & & & & \\
\hline 20 & & & & & & & & & & & & & \\
\hline Total & 4.9 & 3.8 & 6.0 & 10.7 & 16.2 & 20.8 & 12.7 & 12.6 & 1.4 & 8.7 & 1.4 & 0.8 & 100 \\
\hline
\end{tabular}

${ }^{*}$ Mean Temperature $=560^{\circ} \mathrm{C}$

Figure 5.

3-D Frequency plot of coal conditions.

this is a variable that cannot be reproduced within the pyrolyser. It is thus reasonable to consider the conditions at each point in space to be constant and thus the burning zone can be represented by a frequency distri- bution with respect to oxygen concentration and temperature.

Figure 5 shows a frequency distribution of temperature and oxygen concentrations in the burning zone of a 


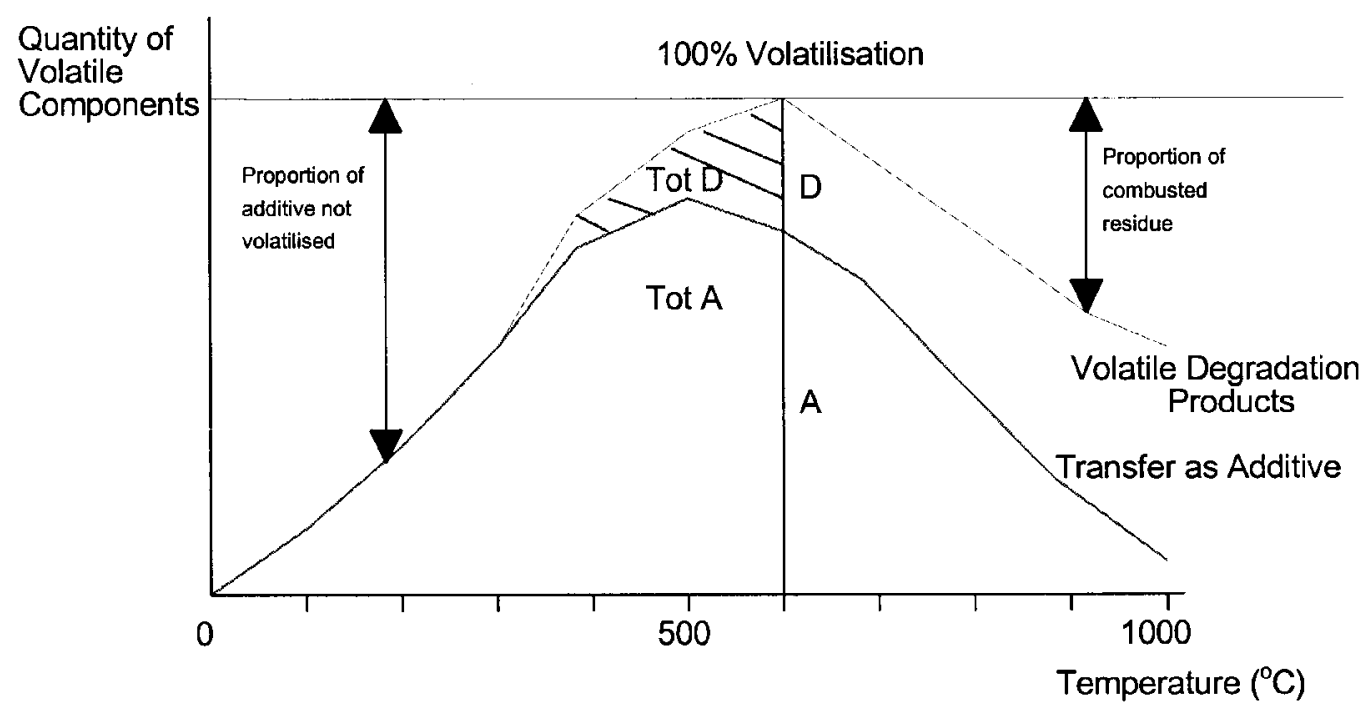

$A=$ Transfer as Additive

$\mathrm{D}=$ Transfer as Decomposition Products

Figure 6.

Additive behaviour in relation to temperature.

cigarette during the first 3 seconds of the puff. (Based on data obtained from reference 6). The frequency data are listed in full in the table below Figure 5.

A detailed picture of the behaviour of an additive in the cigarette could have been established by conducting the experiment at each of the sets of conditions indicated and weighting each result by the percentage frequency. However, obtaining over 50 different combustion profiles would have been unacceptably time consuming and so the calculation for each additive was based on a simplified scheme in which the individual oxygen concentrations were aggregated into two sets of conditions $2 \%$ and $10 \%$ oxygen in nitrogen. This only required a total of 14 individual chromatograms of the pyrolysis products obtained at $100^{\circ} \mathrm{C}$ temperature intervals between $200^{\circ} \mathrm{C}$ and $900^{\circ} \mathrm{C}$.

Predicting the behaviour of a volatile additive from the pyrolysis data

Pyrolysis data obtained under different sets of conditions can help us to understand how the additive may behave in the cigarette. Consider the graph shown in Figure 6 in which the amount of volatile components is plotted in relation to the temperature applied to an additive. At low temperature, i.e., up to $300^{\circ} \mathrm{C}$, some of the additive is volatilised, but most of it remains behind. At $600{ }^{\circ} \mathrm{C}$ the amount of vapour produced is quantitative, i.e., $100 \%$ of the additive is either volatilised or produces volatile degradation products. Above this temperature the proportion of volatile species be- gins to decline as a greater degree of non-volatile residue is produced.

Assuming a steady increase of temperature, none of the additive would remain in the cigarette once the temperature of $600^{\circ} \mathrm{C}$ had been exceeded. The proportion of additive transferring to the vapour phase intact would be given by:

$$
\int_{0}^{600} A /(A+D) \cdot d T
$$

and the proportion of volatile degradation products would be given by:

$$
\int_{0}^{600} D /(A+D) \cdot d T
$$

with the proportion of each volatile component given by:

$$
\begin{aligned}
& \int_{0}^{600} D_{1} /(A+D) \cdot d T+ \\
& \int_{0}^{600} D_{2} /(A+D) \cdot d T \ldots+ \\
& \int_{0}^{600} D_{n} /(A+D) \cdot d T
\end{aligned}
$$

Figure 6 represents a somewhat idealised view of combustion behaviour. It would be possible for example for 
$(A+D)$ to fall short of $100 \%$ in the case of a non-volatile additive and for $(A+D)$ to exceed $100 \%$ if the combustion products were to combine with significant amounts of oxygen.

When we come to consider the distribution of conditions in the burning zone and the effect of dwell time, the relative proportions of each component in the smoke are actually calculated from empirical data. The following example explains how the idealised plot shown in Figure 6 can be related to real pyrolysis data. Figure 7 shows the evolution of $p$-anisaldehyde when heated in $2 \%$ oxygen, together with all its degradation components, which indicates that the release of components in this case is quantitative at around $400{ }^{\circ} \mathrm{C}$ to $500^{\circ} \mathrm{C}$. Thus from this data, only the sets of conditions from $200{ }^{\circ} \mathrm{C}$ up to $500{ }^{\circ} \mathrm{C}$ would be pertinent when calculating the extent of transfer of anisaldehyde in a burning cigarette. Furthermore, at $400{ }^{\circ} \mathrm{C}$ to $500{ }^{\circ} \mathrm{C}$ virtually all the $p$-anisaldehyde transfers intact.

\section{Assumptions and limitations of the method}

It would be misleading to give the impression that by considering the actual conditions in the cigarette and making allowances for volatility, it could be possible to predict the exact effect of a particular additive upon the composition of the smoke. Therefore, before focussing attention on the results, it would be useful to consider the main assumptions behind the pyrolysis method so that the limitations of the technique can be fully understood. The following assumptions and limitations apply:

- Although the range of components covered by the technique is very broad in chromatographic terms, the method does not cover every potential component or group of components. Small gas phase molecules (e.g., CO, ammonia, $\mathrm{HCN}$ ), which are not retained on the column, are effectively excluded from this study. Some other compounds (e.g., nitrosamines, hydrazine, aromatic amines, higher PAH's) require specific methods of sample preparation and detection.

- The conditions in the pyrolyser furnace were held constant over 30 seconds, whereas, during a puff, the conditions in the burning zone would be changing dynamically.

- The model of burning zone conditions was based upon measurements of the gas phase temperatures. These conditions are likely to be appropriate when distillation is the predominant transfer mechanism, but might be less applicable where the additive takes part in the combustion or pyrolysis processes in the cigarette.

- No account was taken of the chemical environment before, during or after the puff. This includes ignoring the effects of additives or substances chemically

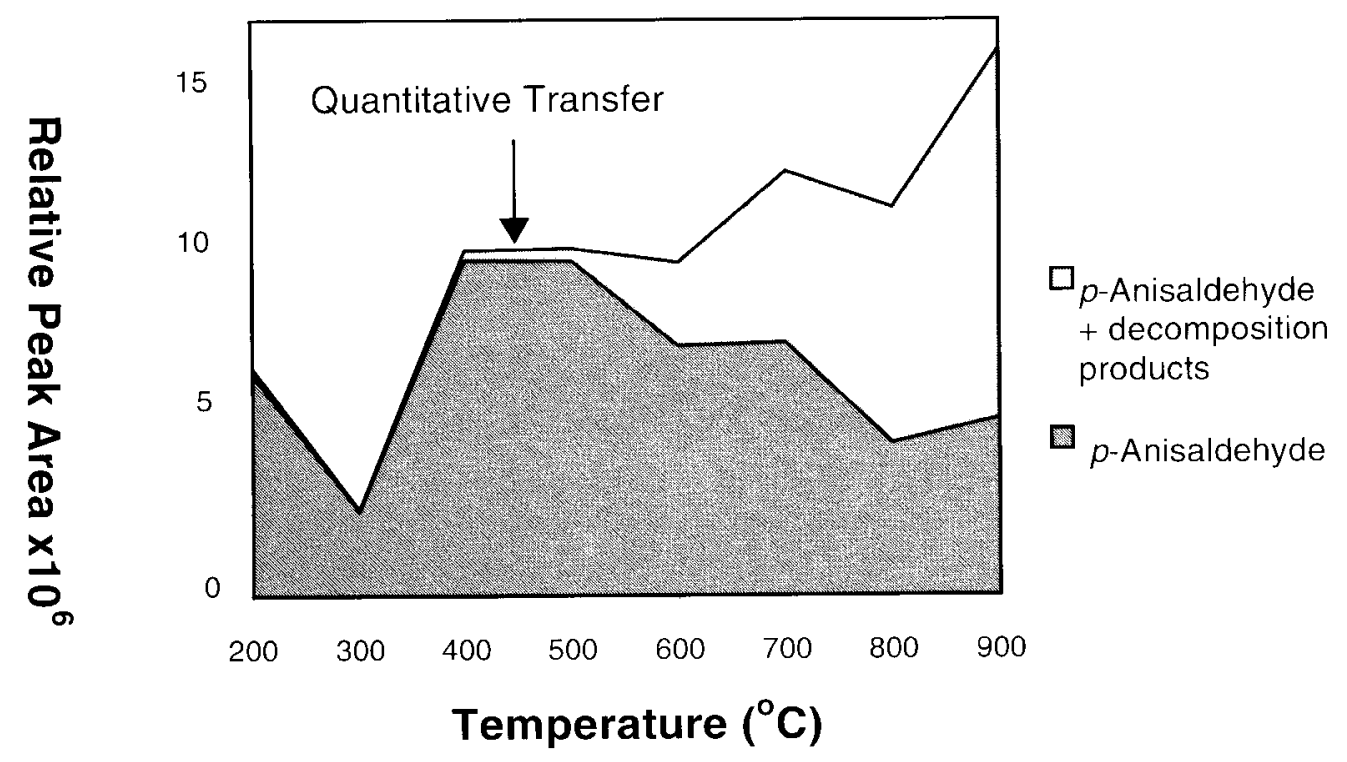

Figure 7.

Pyrolysis of $p$-anisaldehyde in $2 \%$ oxygen in nitrogen. 
or physicall bound in the matrix, the presence of other gases and vapours within the burning zone or the effect of condensation and re-volatilisation.

Overall, then, no matter how much effort is made to take real smoking conditions into account, pyrolysis data should usually be verified with measurements from actual cigarette smoke. Data from individual pyrolysis or combustion experiments are likely to be better for predicting qualitative or semi-quantitative changes rather than fully quantitative changes from cigarette additives to the overall smoke composition. Some of these limitations, i.e., ignoring chemical interferences and only using gas phase temperatures, indicate that this approach is likely to be better for assessing the impact of additives which do not bind chemically with the matrix, rather than for components inherent to the tobacco.

\section{Results and discussion of the pyrolysis data from the additives}

Peak areas of individual substances were calculated by integration from the chromatograms obtained under each of the pyrolysis conditions for anisole, $p$-anisaldehyde, benzaldehyde, isoamyl isovalerate, methyl trans- cinnamate and vanillin. From these data, potential smoke concentrations were calculated, with factors based on frequency data, representing the relative likelihood of each additive experiencing a particular set of conditions in the burning zone of the cigarette. This provides an estimate of the contribution to the smoke chemistry from each of the additives as discussed above. Table 2 shows the weighting factors used in each of the following three different scenarios:

i. The additive distils down the cigarette rod at a relatively low temperature. Pyrolysis results indicate that vanillin, anisole, benzaldehyde and isoamyl isovalerate should transfer completely under such conditions.

ii. An intermediate situation, whereby some of the additive distils, but some remains in the burning zone for part of the puff cycle. Pyrolysis results indicate that methyl trans-cinnamate and $p$-anisaldehyde are likely to transfer quantitatively at around $400{ }^{\circ} \mathrm{C}$.

iii. The additive is held in the burning zone throughout the complete puff cycle and experiences a full range of conditions (the extreme case scenario). This is unlikely to be relevant to any of the additives featured in this study.

Table 2.

Weighting factors applied to pyrolysis data.

\begin{tabular}{|c|c|c|c|}
\hline Experimental conditions & $\begin{array}{l}\text { Distillation at } 200^{\circ} \mathrm{C} \\
\text { (i) }\end{array}$ & $\begin{array}{c}\text { Distillation at } 400^{\circ} \mathrm{C} \\
\text { with some decomposition } \\
\text { (ii) }\end{array}$ & $\begin{array}{c}\text { Held in burning zone } \\
\text { throughout the puff (extreme } \\
\text { case scenario) } \\
\text { (iii) }\end{array}$ \\
\hline $200^{\circ} \mathrm{C}, 2 \%$ Oxygen & $68 \%$ & $23 \%$ & $5.9 \%$ \\
\hline $200{ }^{\circ} \mathrm{C}, 10 \%$ Oxygen & $32 \%$ & $11 \%$ & $2.8 \%$ \\
\hline $300^{\circ} \mathrm{C}, 2 \%$ Oxygen & - & $17 \%$ & $4.2 \%$ \\
\hline $300{ }^{\circ} \mathrm{C}, 10 \%$ Oxygen & - & $7 \%$ & $1.8 \%$ \\
\hline $400^{\circ} \mathrm{C}, 2 \%$ Oxygen & - & $27 \%$ & $6.8 \%$ \\
\hline $400^{\circ} \mathrm{C}, 10 \%$ Oxygen & - & $15 \%$ & $3.9 \%$ \\
\hline $500^{\circ} \mathrm{C}, 2 \%$ Oxygen & - & - & $8.8 \%$ \\
\hline $500^{\circ} \mathrm{C}, 10 \%$ Oxygen & - & - & $7.3 \%$ \\
\hline $600^{\circ} \mathrm{C}, 2 \%$ Oxygen & - & - & $14.9 \%$ \\
\hline $600^{\circ} \mathrm{C}, 10 \%$ Oxygen & - & - & $6 \%$ \\
\hline $700^{\circ} \mathrm{C}, 2 \%$ Oxygen & - & - & $18 \%$ \\
\hline $700^{\circ} \mathrm{C}, 10 \%$ Oxygen & - & - & $0.9 \%$ \\
\hline $800^{\circ} \mathrm{C}, 2 \%$ Oxygen & - & - & $18.2 \%$ \\
\hline $900{ }^{\circ} \mathrm{C}, 2 \%$ Oxygen & - & - & $0.4 \%$ \\
\hline
\end{tabular}


Table 3.

Pyrolysis and smoke chemistry: estimates for additives transferring intact.

\begin{tabular}{l|c|c}
\hline \multicolumn{1}{c|}{ Additive } & $\begin{array}{c}\text { Measured from }{ }^{14} \text { C-labelled } \\
\text { additives in smoke (5) }\end{array}$ & $\begin{array}{c}\text { Transfer intact:predicted from } \\
\text { the pyrolysis results }\end{array}$ \\
\hline Vanillin & $100 \%{ }^{*}$ & $100 \%$ \\
Anisole & $100 \%$ & $97 \%$ \\
Benzaldehyde & $100 \%$ & $74 \%$ \\
Isoamyl isovalerate & $100 \%$ & $99.6 \%$ \\
$p$-Anisaldehyde & $91.4 \%$ & $97 \%$ \\
Methyl trans-cinnamate & $100 \%$ & $98.8 \%$ \\
\hline
\end{tabular}

* However, some decomposition was suspected because of incomplete recovery of the labelled additive.

The results for scenario i., pyrolysis of the additives at $200{ }^{\circ} \mathrm{C}, 2 \%$ and $10 \%$ oxygen indicate transfer to the smoke at $97 \%, 73.5 \%, 99.6 \%$ and $100 \%$ intact respectively for anisole, benzaldehyde, isoamyl isovalerate and vanillin (see Tables 4 to 7 ).

For scenario ii. which includes all conditions up to $400{ }^{\circ} \mathrm{C}$, the results indicate that $98.8 \%$ of methyl transcinnamate and $97 \%$ of $p$-anisaldehyde transfer to the smoke intact (see Tables 8 and 9).

The effect of holding the additive in the burning zone throughout the whole puff (scenario iii.) was also investigated. The results show that there would be a significant level of decomposition for all of the additives. Theoretical transfer values of $74 \%, 69 \%, 64 \%, 63 \%$, $52 \%$ and $50 \%$ respectively were estimated for anisole, $p$-anisaldehyde, benzaldehyde, isoamyl isovalerate, methyl trans-cinnamate and vanillin under these conditions. The purpose of looking at the combustion behaviour over this more extreme range of conditions is to get a feel for a wide range of possible degradation products. Over 100 different decomposition products were identified for vanillin, $p$-anisaldehyde and methyl trans-cinnamate. Fewer components were identified from anisole, benzaldehyde and isoamyl isovalerate.

In most cigarette designs and under most smoking conditions, the 'predictions' from an extreme case scenario are highly unlikely; all of these additives are likely to transfer intact to the smoke mainly by distillation. However, if any of these additives were to be somehow physically or chemically bound within the burning zone, these higher levels of degradation would be significant.

In a previous study of ${ }^{14} \mathrm{C}$-analogues of these additives (5), $p$-anisaldehyde was the only additive found to undergo any decomposition when smoked, with an estimated $91.4 \%$ transfer to the smoke intact. There was no evidence of any decomposition from anisole, benzaldehyde, methyl trans-cinnamate or isoamyl isovalerate.

The authors were unable to recover $100 \%$ of the activity from the added vanillin in their experiments. Because they had measured ${ }^{14} \mathrm{CO}$ in the sidestream vapour, they reasoned that up to $13 \%$ of the vanillin could also have produced ${ }^{14} \mathrm{CO}$ or other decomposition products in the mainstream vapour phase, despite the fact that none were detected. Table 3 shows the proportion of each additive transferring intact according to the ${ }^{14} \mathrm{C}$ smoke results of GREEN et al. (5) compared with our pyrolysis predictions:

The high levels of transfer predicted from the pyrolysis data were largely consistent with GREEN's results. However, the pyrolysis prediction for benzaldehyde transfer at $74 \%$ is much lower than that found by GREEN. This apparent underestimate was due to a single degradation compound formed from pyrolysis of benzaldehyde at a temperature under $200{ }^{\circ} \mathrm{C}$, benzoic acid. Both benzaldehyde and benzoic acid appeared relatively resilient to further degradation, even under higher temperature regimes of $800^{\circ} \mathrm{C}$ to $900^{\circ} \mathrm{C}$.

This result was so at odds with GREEN's data that we originally thought that the benzoic acid might be from an impurity in this particular batch of benzaldehyde. However, this was quickly refuted by injecting a dilute solution of the benzaldehyde on a gas chromatograph there were no detectable impurities in the substance at all.

To explore this a stage further, a number of flue-cured cigarettes was spiked by injection with up to $500 \mu \mathrm{g} / \mathrm{cig}$ of benzaldehyde. The resultant particulate phase was extracted in methanol and a small volume of the extract injected onto GC-MS. Figure 8 shows a plot of the measured benzaldehyde and benzoic acid concentration in the smoke against the quantity of benzaldehyde in the spike added to the cigarette. There was no observable in- 
Table 4.

The predicted transfer of anisole.

\begin{tabular}{c|c|c}
\hline Retention time $(\min )$ & Compound & $\begin{array}{c}\text { Estimated transfer }(\%) \\
\text { at } 200{ }^{\circ} \mathrm{C}, 2 \% \text { and } 10 \% \text { oxygen }\end{array}$ \\
\hline 7.30 & Anisole & 97.0 \\
8.80 & $o-$ Methylanisole & 1.6 \\
9.00 & $p$-Methylanisole & 1.5 \\
\hline
\end{tabular}

Table 5.

The predicted transfer of benzaldehyde.

\begin{tabular}{c|lc}
\hline Retention time $(\mathrm{min})$ & \multicolumn{1}{|c|}{ Compound } & $\begin{array}{c}\text { Estimated transfer (\%) } \\
\text { at } 200{ }^{\circ} \mathrm{C}, 2 \% \text { and } 10 \% \text { oxygen }\end{array}$ \\
\hline 8.06 & Benzaldehyde & 73.5 \\
12.18 & Benzoic acid & 26.3 \\
20.78 & Diphenyl ethanedione & 0.1 \\
3.61 & Toluene & 0.05 \\
\hline
\end{tabular}

Table 6.

The predicted transfer of isoamyl isovalerate.

\begin{tabular}{c|c|c}
\hline Retention time (min) & Compound & $\begin{array}{c}\text { Estimated transfer (\%) } \\
\text { at } 200^{\circ} \mathrm{C}, 2 \% \text { and } 10 \% \text { oxygen }\end{array}$ \\
\hline 10.50 & Isoamyl isovalerate & 99.6 \\
8.70 & Isobutyl isovalerate & 0.4 \\
\hline
\end{tabular}

Table 7.

The predicted transfer of vanillin.

\begin{tabular}{|c|c|c|}
\hline Retention time ( $\mathrm{min}$ ) & Compound & $\begin{array}{l}\text { Estimated transfer }(\%) \\
\text { at } 200^{\circ} \mathrm{C}, 2 \% \text { and } 10 \% \text { oxygen }\end{array}$ \\
\hline 14.75 & Vanillin & 100 \\
\hline
\end{tabular}


Table 8.

The predicted transfer of methyl cinnamate.

\begin{tabular}{|c|c|c|}
\hline Retention time (min) & Compound & $\begin{array}{l}\text { Estimated transfer (\%) } \\
\text { at all conditions up to and } \\
\text { including } 400^{\circ} \mathrm{C}\end{array}$ \\
\hline 14.20 & Methyl cinnamate & 98.8 \\
\hline 16.30 & 2,6-bis(1,1-dimethylethyl)-4-methylphenol & 0.8 \\
\hline 15.32 & Methyl $\alpha$-methylcinnamate & 0.1 \\
\hline 15.32 & 4-Methylstyrene & 0.1 \\
\hline 14.48 & 1-Methoxyethylbenzene & 0.1 \\
\hline 14.47 & 2-propanone, 1-(4-methoxyphenyl)-oxime & 0.03 \\
\hline 15.93 & 2,6-di-t-butyl-4-methylene-2,5-cyclohexadiene-1-one & 0.02 \\
\hline 14.53 & 2-(1-Methylethyl) phenol & 0.02 \\
\hline 15.36 & 1-Propynylbenzene & 0.02 \\
\hline 15.30 & Methyl 2-benzylacrylate & 0.01 \\
\hline 15.37 & Indene & 0.01 \\
\hline
\end{tabular}

Table 9.

The predicted transfer of $p$-anisaldehyde.

\begin{tabular}{c|l|c}
\hline Retention time $(\mathrm{min})$ & \multicolumn{1}{c|}{ Compound } & \multicolumn{1}{c}{$\begin{array}{c}\text { Estimated transfer (\%) } \\
\text { at all conditions up to } \\
\text { and including } 400^{\circ} \mathrm{C}\end{array}$} \\
\hline 12.79 & $\begin{array}{l}\text { p-Anisaldehyde } \\
12.59\end{array}$ & $\begin{array}{c}\text { Methyl-p-hydroxybenzoate } \\
14.45\end{array}$ \\
12.33 & Methyl-4-methoxybenzoate & 1.0 \\
15.25 & 4-Methoxyphenol & 0.9 \\
12.18 & Anisic acid & 0.3 \\
12.19 & 1,1-dimethoxy-2-propanal & 0.3 \\
12.66 & 2-Methoxyphenol & 0.2 \\
\hline
\end{tabular}

crease in benzoic acid from the $100 \mu \mathrm{g} / \mathrm{cig}$ spike, but at the higher spike concentration an increase in both benzaldehyde and benzoic acid was clearly visible.

These results show that benzaldehyde is likely to produce benzoic acid in cigarette smoke under normal smoking conditions. However, it is not clear why benzoic acid was not found in the smoke in GREEN's study since the labelled carbon would be retained upon oxidation.

The pyrolysis results for $p$-anisaldehyde and methyl trans-cinnamate indicated a higher transfer temperature, which translated to a very slight increase in the amount of decomposition relative to most of the other flavourants. In the case of $p$-anisaldehyde the predicted 


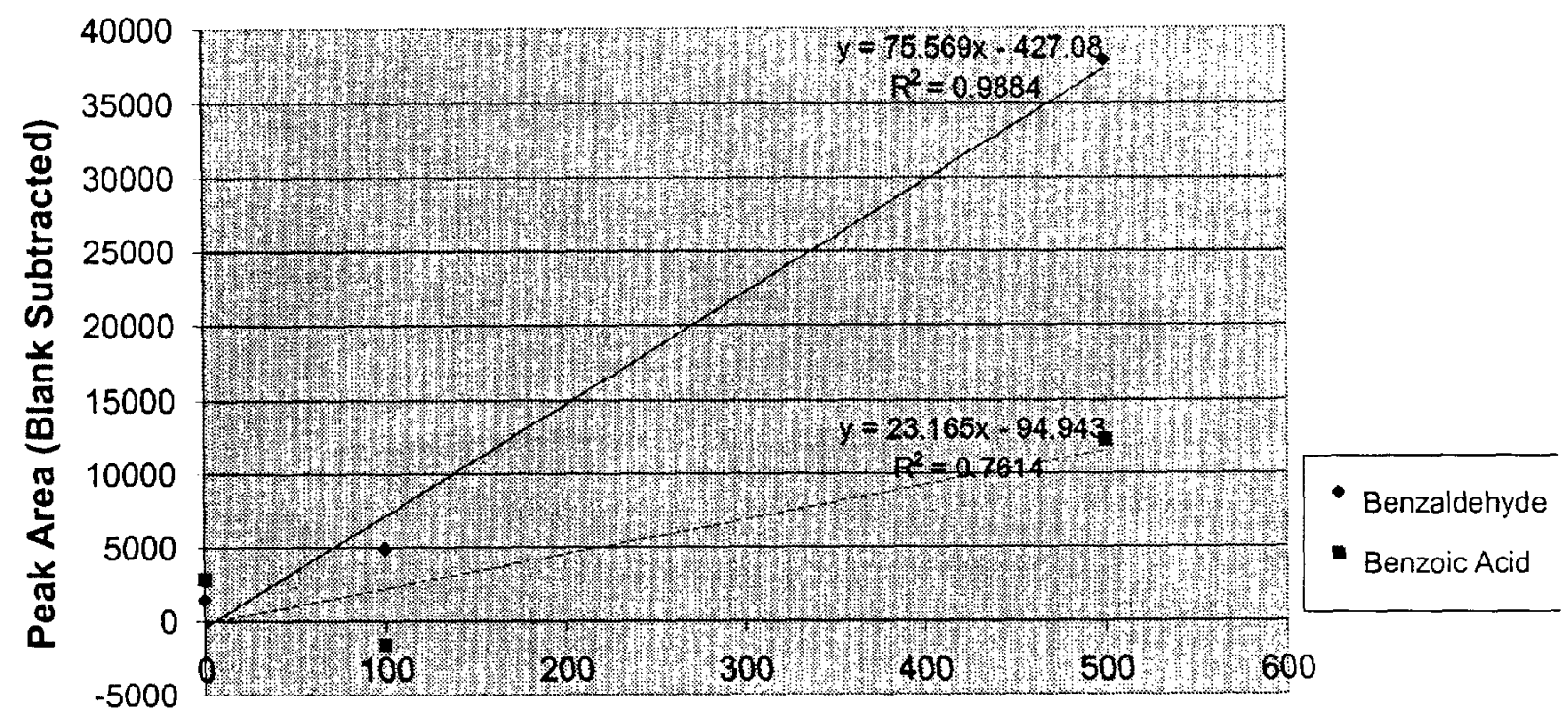

Spike (ug)

Figure 8.

Benzaldehyde and benzoic acid in smoke from spiked cigarettes.

decomposition was not as great as that predicted by GREEN et al. This could be due to a number of factors: GREEN's experiments did not exclude the possibility of an active impurity present in the p-anisaldehyde. Alternatively, because the pyrolysis method highlighted mostly high boiling point compounds, an abundance of low boiling point vapour phase degradation products would be underestimated by this approach. However, it is quite likely that this apparent discrepancy was due to random experimental errors associated with both methods. In this case all we can conclude is that over $90 \%$ of $p$-anisaldehyde transfers intact, while between 3 to $10 \%$ transfers as degradation products.

\section{CONCLUSIONS}

The work described in this paper demonstrates that pyrolysis can be applied usefully to the study of smoke chemistry provided that (a) the experiments are done under conditions relevant to those in a burning cigarette and (b) the limitations of the technique are understood.

It is therefore essential to consider an appropriate range of different burning zone conditions when designing the experiments. Non-volatile substances need to be evaluated over a full range of conditions; volatile sub- stances can be considered over an appropriate lowe temperature range.

Conducting pyrolysis experiments at different sets o conditions enables a more fundamental understanding o the relationship between individual combustion condi tions and the overall smoke chemistry.

Pyrolysis experiments indicate that in a burning ciga rette during puffing, vanillin, anisole, and isoamy isovalerate are likely to transfer to the smoke intact a $200^{\circ} \mathrm{C}$. Methyl trans-cinnamate and $p$-anisaldehyde ar likely to transfer to the smoke at a higher temperature i.e., $400^{\circ} \mathrm{C}$, and appear to be subject to a small amoun of degradation $(1-3 \%)$.

In the pyrolyser, about a quarter of the benzaldehydi undergoes oxidation to benzoic acid at a relatively lon temperature (less than $200^{\circ} \mathrm{C}$ ) but both compound: resist much further degradation, even at high tempera tures. Although GREEN and his co-workers did not ob serve any degradation of benzaldehyde in their experi ments, our analysis of cigarettes spiked with benzalde. hyde indicates that oxidation of benzaldehyde to ben. zoic acid occurs in the smoke.

The levels of additive transfer indicated by the pyrolysis predictions for the other flavours in this study agree wel. with GREEN's results (5). In the case of p-anisaldehyde the amount of decomposition predicted by the pyrolysis was not as great as that found by GREEN et al. 
1. Schlotzhauer W.S. and O.T. Chortyk: Recent advances in studies on the pyrosynthesis of cigarette smoke constituents; J. Anal. Appl. Pyrolysis 12 (1987) 193-222.

2. Jenkins R.W. Jr. and D.D. McRae: Fifty years of research on cigarette smoke formation and delivery at the Tobacco Chemists' Research Conference; Recent Adv. Tob. Sci. 22 (1996) 337-392.

3. Schmeltz I. and W.S. Schlotzhauer: Benzo[a]pyrene, phenols and other products from the pyrolysis of the cigarette additive, $(d, l)$-menthol; Nature 219 (1968) 370-371.

4. Jenkins R.W. Jr., R.H. Newman and M.K. Chavis: Cigarette smoke formation studies; Beitr. Tabakforsch. 5 (1970) 299-301.

5. Green J.D., J. Chalmers and P.J. Kinnard: The transfer of tobacco additives to cigarette smoke (examination of the possible contribution of pyrolysis products to mainstream smoke composition); Beitr. Tabakforsch. Int. 14 (1989) 283-288.

6. Baker R.R.: Variation of the gas formation regions within a cigarette combustion coal during the smoking cycle; Beitr. Tabakforsch. Int. 11 (1981) 1-17.
Address for correspondence

Steve Stotesbury,

British American Tobacco,

$R E D$ Centre,

Regents Park Road,

Millbrook, Southampton, SO15 8TL,

United Kingdom 